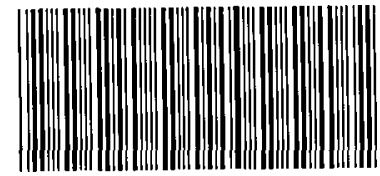

005049006

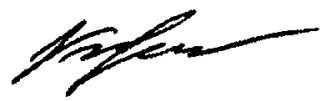

Коровяковский Плья Владимирович

Советский фактор в развитии экономики Демократической Республики Въетнам (середина 1950-х - середина 1970-х гг.)

Специальность

07.00 .03 - всеобшая история

(новая и новейпая нстория)

\title{
Автореферат
}

диссертации на соискапие учёной степени

кандидата исторических наук

Курск 2012 
Работа выполнена на кафедре всеобщей истории Курского государственного университета

Научный руководитель:

Официальные отпоненты:

Ведупая организация: доктор исторических наук, профессор Конорева Крита Александровна

доктор исторических наук, профессор ФГАОУ ВПО «БелГородский государственный национальный исследовательский университет» Малай Вера Владимировна кандидат исторических наук, преподаватель НОУ СПО «Курский техиикум экономики и права» Веревкина Юлия Ивановна

Воронежский тосударственный унивсрситет.

Защиита состоится 28 декабря 2012 года в 16.00 пасов на заседании диссертационного совета Д 212.104.04 в Курском государственном университете по адресу: 305000 , г. Курск, ул. Радишева, д. 33, конференц-зал.

С диссертацией можно ознакомиться в библиотеке Курского государственного университета.

Автореферат разослан 26 ноября 2012 года.

Ученый секретарь диссертациониого совета

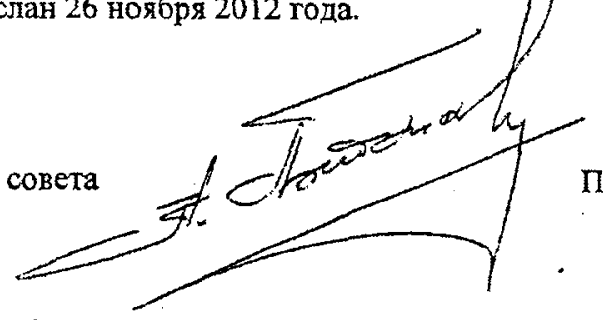

Постников Н.А 


\section{ОБЩАЯ ХАРАКТЕРИСТИКА ДИССЕРТАЦИИ}

Актуальность темы исследования. Активизация восточного направления внешней политики России обуславливает значительное расширение экономического сотрудничества со странами Юго-Восточной Азии. Развитие отношений с Социалистической Республикой Вьетнам (СРВ) является важной долгосрочной внешнеполитической задачей РФ. В последние годы экономические отношения России с СРВ имеют положительную динамику', однако они еще не в полной мере соответствуют потенциалу сторон. Это, в свою очередь, вызывает необходимость исторического анализа опыта экономического сотрудничества их предшественников - Демократической Республики Вьетнам (ДРВ) и Советского Союза.

Как известно, во второй половине $\mathrm{XX}$ в. ДРВ и СССР являлись экономическими партнерами и военно-политическими союзниками. Советский Союз оказывал ДРВ значительную материальную помощь в преодолении экономической отсталости и последствий Второй индокитайской войны (19651973 гг.) При техническом содействии СССР были заложены основы вьетнамской национальной экономики, подготовлены высокопрофессиональные кадры для многих отраслей народного хозяйства.

Распад СССР нарушил сложившиеся связи, и лишь в последние годы они постепенно восстанавливаются, но уже на принципиально новой, прагматичной основе $^{2}$. В то же время, являясь материальной базой двусторонних отношений, экономическое сотрудничество, безусловно, остается тем фактором, которому суждено определять характер будущего взаимодействия России и Вьетнама. Изучение истории взаимоотношений между ДРВ и СССР поможет выявить возможные перспективы российско-вьетнамского сотрудничества.

Объектом диссертационного исследования является история межгосударственных отношений стран социалистического лагеря в середине 1950-х-середине $1970-$ х гг.

Предмет исследования - фактор советского экономического участия в процессе становления и развития экономики ДРВ.

В диссертации отдельно не рассматривается военная помощь ДРВ со стороны СССР, так как материалы архивных фондов, относящиеся к данному вопросу, недоступны для исследователей. Кроме того, мы не акцентировали внимание на геополитической составляющей при определении мотивов советской экономической помощи, поскольку данный аспект достаточно полно исследован в отечественной историографии.

' 27 июля 2012 г. главы государств РФ и СРВ подписали «Совместное заявлсние об укреплении отношений всеобъемлющего стратетического партнёрства между Российской Федерацией и Социалистической Республикой Вьетнам» - http: // news. kremlin.ru/ref notes/1279.

2 Кобелев Е.В. Современный Вьетнам: реформы, обновление, модернизация (1986-1997). М., 1999; его же: Российско-вьетнамские отношения: история и современность // Позиции России в АТР. М., 2007 ; Селиванов И.Н. Внешняя политика государств Индокитая // Индокитай: 1990-е годы (политика, экономика). М., 1999; Мазырин В.М. Реформы переходного периода во Вьетнаме (1986-2006): направления, динамика и результаты. М., 2007; его же: Россия в Нндокитае: Назад в будущее? // Международная жизнь. 2010. №l1; его же: Новые тенденции и актуальные проблемы экономических отношений между Россией и Вьетнамом // Проблемы Дальнего Востока. 2010. № 4 и др. 
Хронологические рамки диссертации охватывают период с середины 1950-х до середины 1970-х гг. - с окончания Первой индокитайской войны и до провозглашения в апреле 1976 г. Социалистической Республики Вьетнам (СРВ).

Внутри обозначенного периода рассмотрены три этапа: 1955 -1965 гг., 1965-1973 гг., январь 1973- апрель 1976 гг.

Первый эman (1955-1965 гг.) - «межвоенное десятилетие». Его выделение обусловлено наличием в тот период в ДРВ конкретных программ по восстановлению экономики страны и закладке фундамента сотрудничества в экономической сфере с возможными партнёрами, в том числе с СССР.

Bmopoй этаn (1965-1973 гг.) охватывает события Второй индокитайской войны, начиная с американских бомбардировок территории ДРВ вплоть до подписания в январе 1973 г. Парижского соглашения по Вьетнаму. Он характеризовался перестройкой экономики Вьетнама на военный лад и определённым изменением характера взаимодействия между ДРВ и СССР.

Tрепий этаn (1973-1976 гг.) включает события, происходившие с января 1973 г. до провозглашения в апреле 1976 г. СРВ. Отличительной особенностью данного периода является снижение интереса к ДРВ со стороны СССР в связи с наметившимся улучшением отношений с США. В экономической сфере это проявилось в сокращении объёмов безвозмездной советской помощи и переходе к политике взаимовыгодного сотрудничества.

Цель работы - определить роль Советского Союза в процессе формирования основ национальной экономики ДРВ.

Из поставленной цели вытекают следуюшие задачи:

- показать исторические условия становления и развития национальной экономики, сложившиеся в ДРВ после окончания Первой индокитайской войны;

- определить степень потребностей ДРВ в помоши со стороны СССР;

- выявить мотивы участия СССР в процессе создания благоприятных условий для формирования основ экономики ДРВ в период между двумя индокитайскими войнами;

- выделить наибоолее важные направления сотрудничества в экономической сфере между ДРВ и СССР в период Второй индокитайской войны;

- охарактеризовать специфику проблем, возникших в экономике ДРВ к моменту объединения Вьетнама в единое государство, вызванных активным внедрением советской модели развития.

Научная новизна исследования. В диссертации экономика ДРВ рассмотрена как составная часть национальной экономики Вьетнама в целом, выделены причины, обусловившие возможность автономного исследования процесса становления и развития национальной экономики Вьетнама в рамках северной части страны - ДРВ.

В работе доказано, что в изучаемый исторический период модель социалистической экономики не была единственно возможной, поскольку вариант Южного Вьетнама с моделью рыночной экономики демонстрировал поступательное развитие, что вполне осознавали и политические лидеры ДРВ. Тем не менее, был взят курс на развитие экономики, основывающейся на социалистической системе хозяйствования, тем более, что КНР и СССР готовы 
были оказать значительную материальную помощь, желая видеть ДРВ своим союзником.

В диссертации проведён анализ мотивов, которыми руководствовались лидеры ДРВ, выстраивая собственные внешнеэкономические связи, в том числе и в отношении СССР.

На основании анализа источников, многие из которых впервые введены в научный оборот, доказано, что политика СССР в отношении ДРВ в середине 1950-x - середине 1970-х гг. отвечала её национальным интересам, сыграв, в целом, позитивную роль для народов данного региона, но имела и негативные последствия, поскольку экономика объединённого Вьетнама унаследовала серьёзные проблемы, заложенные в принципах административно-командной системы.

К новизне исследования следует отнести его междисциплинарный характер, поскольку в диссертации наряду с историческими, использовались методы экономических наук.

Методологическую основу исследования составили основные принципы исторического познания - историзм и объективность. Они предполагают изучение предмета исследования в динамике его развития с учётом постоянно меняющихся внутри- и внешнеполитических факторов, а также стремление к объективным оценкам посредством использования как можно большего количества источников и конструктивного критического осмысления имеющихся на сегодняшний день теоретических обобшений.

Принципы историзма и объективности в диссертации сочетаются с ценностным и системным подходами, что позволяет, с одной стороны, уважительно относиться к наследию предшествующих поколений исследователей, с другой - ориентирует на постановку новых задач в изучении предмета исследования.

В ходе работы применялись общенаучные методы - анализ и синтез.

Из специальных исторических методов использовались историкогенетический, историко-сравнительный, историко-системный, ретроспективный и колнчественный.

Исследование роли и места фактора советского экономического участия в процессе становления и развития ДРВ изложено на основе проблемно хронологического подхода.

Практическая значимость исследования заключается в возможности использования материалов диссертации при написании обобщающих трудов по истории и экономике стран Индокитая, а также при разработке спецкурсов по истории стран Азии, курсов лекций и методических пособнй по истории мировой экономики и международных отношений.

Источниковая база исследования. При написании диссертационного исследования использовались как неопубликованные, так и опубликованные исторические источники, которые условно разделены на шесть групп.

Основную часть источниковой базы составили материалы центральных российских архивов, которые отнесены к первой группе источников. 
Значительный объём документов, непосредственно относящийся к вопросам экономического сотрудничества ДРВ и СССР, содержится в фондах Российского государственного архива экономики (РГАЭ). В Фонде Управления по делам научно-технического сотрудничества с социалистическими странами (УНТС) Государственного Комитета Совета Министров СССР по науке и технике за 19531965 гг., имеются отчёты о выполнении обязательств, протоколы, переписка сотрудников посольств, материалы по передаче и получению технической документации, по организации научно-технического сотрудничества и др. ${ }^{3}$

В Фонде Учреждения по внешнеэкономическим связям 1955-1988 гг. размещены материалы заседаний экономической комиссии ООН для стран Азии и Дальнего Востока, переписка МИД СССР и советских организаций по вопросам кооперативно-экономического развития Южной и Юго-Восточной Азии ${ }^{4}$.

В Фонде 9503 представлены документы Комитета по участию СССР в международных энергетических объединениях (СовМЭК) Государственного Комитета Совета Министров СССР по науке и технике 1946-1987 гг. Определенный интерес представляют документы Международной Комиссии по большим плотинам (СИГБ) за 1946-1975 гг. ${ }^{5}$ Наибольший интерес представляют материалы из Фонда Государственного Комитета СССР по внешним экономическим связям. В материалах (датированных 1948-1976 гг.) представлены контракты и договоры СССР с Вьетнамом ${ }^{6}$ В Фонде Постоянного представительства СССР при Совете Экономической Взаимопомощи периода 1964-1987 гг. представлены Протоколы с приложениями (планы, отчёты, договоры, программы и др. $)^{7}$

В Фонде 413 Министерства внешней торговли СССР содержатся документы Управления торговли со странами Азии, отчеты советских работников посольств и торгпредств.

Знакомство с материалами РГАЭ позволяет сделать вывод о том, что вопросу советско-вьетнамского экономического сотрудничества уделялось большое внимание, что нашло отражение в заключении многочисленных соглашений и договоров между отраслями и ведомствами.

Кроме того, документы экономического содержания направлялись в МИД СССР, что нашло отражение в фондах Архива внешней политики РФ (АВП РФ). Материалы по исследуемой проблеме представлены в фондах 79 «Референтура по Вьетнаму» ${ }^{8}, 079$ «Секретная референтура по Вьетнаму» ${ }^{9}, 540$ «Посольство СССР в Демократической Республике Вьетнам» ${ }^{10}$. В них содержатся материалы, как правило, не публиковавшиеся в открытой печати: официальные заявления, переписка должностных лиц, аналитические записки сотрудников посольств, информация о поставках, официальные обращения правительства ДРВ в Москву

\footnotetext{
${ }^{3}$ РГАЭ. Ф. 9493. Оп. 1. Д. 1154-1162; Оп. 5. Д. 2180

${ }^{4}$ РГАЭ. Ф. 365. Оп, 1. Д. 25. и цр.

${ }^{5}$ РГАЭ. Ф. 9503 . Оп. 1. Д. 531 ; Оп. 2. Д. 512.

${ }^{6}$ РГАЭ. Ф. 62. Оп. 1. Д.11190. и др.

${ }^{7}$ РГАЭ. Ф.302 (кат. 1.4295). Оп. 1: Оп. 5. и др.

${ }^{8}$ АВП РФ. Ф. 79. Оп. 8. Д. 3; Оп. 1 1а. Д. 10; On. 28. Д.10; Оп. 34. Д. 11; Оп. 19. Д.12 и др.

${ }^{9}$ АВП РФ. Ф. 079. On 4. Д. 720; Оп. 7. Д. 110; Оп. 8. Д. 3 и др.

${ }^{10}$ АВП РФ. Ф. 540 . Оп. 4. Д. 21.
} 
об оказании экономической и военной помощи и т.п. Документы АВП РФ позволили расширить имеющиеся представления о сотрудничестве между ДРВ и СССР в период Второй индокитайской войны, а также специфике сотрудничества в условиях улучшения отношений между СССР и США.

В фондах Российского государственного архива научно-технической документации (РГАНТД) (филиал в г. Самара) имеются документы, относящиеся к исследуемому нами периоду: Фонд института «Промстройпроект» содержит документацию по проектированию дизельного завода в провинции Винь-Хук (1960-1963 гг.), завода цветных металлов в г. Нам-пхо (1954-1956 гг.); материалы по проектированию в 1963 г. завода лекарственных препаратов; Фонд института «Гипрорыбпром» - документы по проектированию рыбоконсервного завода, холодильника и причала в г. Хайфон в 1960-1967 гг.; Фонд института «Гипрохим» - документацию по проектированию суперфосфатного завода в г. Лам-Тао в 1957-1959 гг.; Фонд Р-621 - документы по проектированию политехнического института в г. Ханое в $1959-1964$ гг; Фонд института «Цветметпром» содержит проектную документацию горно-обогатительного комбината и т. п. ${ }^{11}$

В состав документов РГАНТД, как правило, входят пояснительные записки, технико-экономические обоснования, рабочие чертежи, письма, приказы, связанные с проектированием объектов на территории Вьетнама, что в определённой степени ограничивает возможность их использования непосредственно в тексте диссертации. Тем не менее, для формирования общего представления о размерах и видах экономического сотрудничества между СССР и ДРВ, ознакомление с ними, несомненно, было полезным.

Bmopyю групnпy источников составляют официальные публикации документов и материалов, освещающих различные вопросы взаимоотношений СССР и государств Индокитая, в частности, ДРВ ${ }^{12}$.

В 2007 г. был издан российско-американский сборник документов «Советско-американские отношения: годы разрядки. 1969-1976», в котором опубликованы материалы из Архива Президента РФ и АВП РФ, охватывающие период 1969-1972 гг. ${ }^{13}$ И хотя конкретных данных по вопросам экономического сотрудничества между СССР и ДРВ там немного, документы представляют интерес с точки зрения выявления реакции американской стороны на действия руководства СССР в Индокитае, в том числе в экономической сфере.

Материалы высших органов КПСС, которые определяли основные направления внешней политики СССР - стенографические отчёты и материалы съездов, Пленумов ЦК КПСС - представляют дополнительный комплекс материалов по вопросам участия СССР в процессе оказания военной помощи и

\footnotetext{
" РГАНТД. Ф. Р-7; Ф. Р-434; Ф. Р-134; Ф. Р-372; Ф. Р-621; Ф. Р-386.

${ }^{12}$ Демократическая Республика Вьетнам. Конституция, законодательные акты, документы. М., 1955; Сборник торговых договоров, торговых и платёжных соглашений СССР с иностранными государствами (на 1-е янв. 1965 г.) М., 1965; Боевая солидарность, братская помощь (Сборник важнейших внешнеполитических документов СССР по вьетнамскому вопросу). М., 1970; Советский Союз-Вьетнам: 30 лет отношении, 1950-1980. Документы и материалы. М., 1982; Сборник действующих договоров, соглашений и конвенций, заключенных СССР с иностранными государствами. Вып. XVII-XVIII, М., 1960 и др.

${ }^{13}$ Советско-амсриканские отнотения: годы разрядки. 1969-1976. В 2-х кн. Кн. I-2. М., 2007.
} 
восстановления экономики ДРВ ${ }^{14}$. Отличительной особенностью этих документов является их идеологическая направленность, позволяющая проанализировать причины столь активного участия СССР в делах Вьетнама.

Значительный объём фактического материала, послужившего для воссоздания исторического фона, на котором строилось вьетнамо-советское экономическое сотрудничество, содержит серия документов по истории внешней политики США за период 1943-1976 гг. ${ }^{15}$ Сборники издавались историческим отделом американского дипломатического ведомства и с ними частично можно познакомиться на сайте Государственного департамента США ${ }^{16}$. На страницах «Congressional Record» ${ }^{17}$ - официального американского издания освещались результаты слушаний в Конгрессе США, которые позволяют выявить отношение членов Конгресса к политике СССР в Индокитае на различных её этапах, в том числе и к её экономической составляющей. Важным источником являются документы Пентагона - «The Pentagon Papers» 1971 г. $^{18}$ Данная подборка документов позволяет составить представление о том, как оценивали участие СССР в процессе укрепления экономики Вьетнама американские политические круги. Для воссоздания исторического фона были также использованы материалы американского издания «US-Vietnam Relations, 1945-1967», «The Department of State Bulletin. South Vietnam: US - Communist Confrontation in Southeast Asia. 1961-1965» и др. ${ }^{19}$

B третью групnу источников вошли работы и сборники выступлений руководителей и видных политических деятелей ДРВ, СССР, США и других государств мира периода 1955-1976 гг. В первую очередь это тексты выступлений вьетнамских политических деятелей - Хо Ши Мина, Ле Зуана, Во Нгуен Зиапа, советских - Н.С. Хрущёва, Л.И. Брежнева, А.А. Громыко, А.Н. Косыгина, американских - Дж. Кеннеди, У. Фулбрайта, Р. Макнамары, Г. Киссинджера и др. $^{20}$ В этих изданиях представлены материалы, позволяющие понять мотивы и причины принятия тех или иных решений по наиболее важным

14 Материалы внеочередного ХХІ съезда КПСС. М., 1960; Материалы ХХII съезда КПСС. М., 1962; Материалы XXIII съезда КПСС. М., 1966; Материалы ХХIV съезда КПСС. М., 1971; Коммунистическая партия Советского Союза в резолюциях и решениях съездов, конференций. М., 1983, Президиум ЦК КПСС. $1954-1964$. Черновые протокольные записи заседаний. Стенограммы. Постановления. М., 2004 и др.

15 Memorandum From Secretary of Defense McNamara to President Johnson. / Kent Sieg, Edward C. Keefer. Foreign Relations of the United States 1964-1968. Volume III, VII, Vietnam, June-December 1965. Wash., 2003;

${ }_{16}^{16} \mathrm{http} . / / \mathrm{www}$. state.gov/www/about_state/history/.

17 Congressional Record. Proccedings and Debates. Wash., 1955-1975.

18 The Pentagon Papers. The Defense Department History of United States. Vietnam. V. I-V. Boston, 1971.

${ }^{19}$ US- Vietnam Relations, 1945-1967. V. 1-4 Wash. 1971.; The Department of State Bulletin, South Vietnam: US - Communist Confrontation in Southeast Asia. 1961-1965. Wahs., 1972 н др.

${ }_{20}$ Хо Ши Мин. Избранные произведения (1920-1969). Ханой, 1973, его же: Избранные статьи и речи: пер с вьетн. и франц. М., 1959; Ле Зуан. Избранные статьи и речи (1970-1975). М., 1975, его же: Октябрьская революция и революция во Вьетнаме. Ханой, 1979; Во Нгуен Зиап. Национально-освободительная война во Вьетнаме. Общая линия, стратегия и тактика. Ханой, 1971; Хрущёв Н.С. За прочный мир и мирное сосуществование. Т. 4. М., 1958, его же: За новые победы мирового коммунистического движения. М., 1961; Брежнев Л.И. Ленинским курсом. Речи и статьи: Т. 1-5. М., 1970-1978; Громыко А.А. Во имя торжества ленинской внешней политики. Избранные речи и статьи. М., 1978; Косыгин А.Н. Заявление правительства о6 основных вопросах внутренней и внешней политики: Выступление Председателя Совета Министров СССР на первой сессии Верховного Совета СССР седьмого созыва 3 августа 1966 г. M., 1966; Kennedy J.F. The Strategy of Peace. N.Y., 1960; Fulbrighte W. The Crippled Giant. American Foreign Policy and Its Domestic Consequences. N.Y., 1972; McNamara R. Essence of Security: Reflections in Office. N.Y., 1968; Kissinger H. American Foreign Policy. Three Essays. N.Y., 1969 и др. 
организаций по вопросам кооперативно-экономического развития Южной и Юго-Восточной Азии 5 .

В Фонде 9503 представлены документы Комитета по участию СССР в международных энергетических объединениях (СовМЭК) Государственного Комитета Совета Министров СССР по науке и технике 1946-1987 гг. ${ }^{6}$ Наибольший интерес представляют материалы из Фонда 62 Внешнеэкономические связи, в частности, Главного инженерного управления (ГИУ) Государственного Комитета СССР по внешним экономическим связям. В материалах (датированных 1948-1976 гг.) представлены контракты и договоры СССР с Вьетнамом ${ }^{7}$ В Фонде 302 (кат. 1.4295) Постоянного представительства СССР при Совете Экономической Взаимопомоши периода 1964-1987 гг. представлены Протоколы с приложениями (планы, отчёты, договоры, программы). ${ }^{8}$

В Фонде 413 Министерства внешней торговли СССР содержатся документы Управления торговли со странами Азии отчеты советских работников посольств и торгпредств.

Знакомство с материалами РГАЭ позволяет сделать вывод о том, что вопросу советско-вьетнамского экономического сотрудничества уделялось большое внимание, что нашло отражение в заключении многочисленных соглашений и договоров между отраслями и ведомствами.

Кроме того, экономические договоры по поставке помощи ДРВ, выдаче и получению кредитов, на строительство промышленных объектов направлялись в МИД СССР, что нашло отражение в содержании фондов Архива внешней политики РФ (АВП РФ). Материалы по исследуемой проблеме представлены в следуюших фондах: Фонд 79 «Референтура по Вьетнаму», Фонд 079 «Секретная) референтура по Вьетнаму» ${ }^{10}$, Фонд 540

${ }^{5}$ РГАЭ. Ф. 365. Оп. 1. Д. 25. и др.

${ }^{6}$ РГАЭ. Ф. 9503. ОП. 1. Д. 531; ОП. 2. Д. 512.

${ }^{7}$ РГАЭ. Ф. 62. ОП. 1. Д.11190. и др.

${ }^{8}$ РГАЭ. Ф.302 (кат. 1.4295). ОП. 1: Оп. 5. и др.

${ }^{9}$ АВП РФ. Ф. 79. Оп. 8. Д. 3; Оп. 11а. Д. 10; Оп. 28. Д. 10; Оп. 34. Д. 11; Оп. 19. Д. 12 и др. 
Источниковая база позволяет решить поставленные в диссертационном исследовании задачи.

\section{Степень изученности темы. В отечественной и зарубежной} историографии отсутствуют специальные комплексные исследования, посвященные изучению роли советского фактора в становлении экономики ДРВ. Имеются лишь работы, в которых рассматриваются отдельные аспекты проблемы, однако в них отсутствует исторический анализ роли СССР в процессе формирования основ национальной экономики Вьетнама.

В отечественной историографии проблемы можно условно выделить два этапа - советский (он включает в себя период 1950-х-1980-х гг.) и постсоветский (с начала 1990-х гг. и вплоть до настоящего времени).

Работы, в которых затрагивался экономический аспект двусторонних отношений, стали появляться в отечественной историографии в период, обозначенный нами в качестве хронологических рамок исследования. Характерным для него являлось большое внимание, которое уделяли исследователи действиям руководства СССР в вопросах сотрудничества со странами Индокитая с акцентом на идеологической составляющей ${ }^{23}$.

Определённый интерес с точки зрения оценок советско-вьетнамского экономического (в большей степени - военного) сотрудничества представляют работы, посвящённые событиям Второй индокитайской войны ${ }^{24}$. Их авторы были единодушны во мнении, что без помощи социалистических стран, без усилий со стороны мировой общественности ДРВ не смогла бы противостоять американской военной машине и успешно решать вопросы организации отпора врагу и создания национальной экономики.

Отношения, в том числе и экономического характера между ДРВ и СССР рассматривались в статьях, опубликованных в периодических изданиях указанного периода ${ }^{25}$. Отличительной особенностью данных публикаций являлось

Vietnam in Military Statistics: A History of the Indochina Wars, 1772-1991. J., 1995 и др.

${ }_{23}$ Нихамин В.П. Международные отношения в Юго-Восточной Азии после второй мировой войны. М., 1956; Мхитарян С.А. Борьба вьетнамского народа за национальную независимость, демократию и мир (1945-1955 гг.) М., 1957; Лаврищев А.А. Нндокитайский вопрос после окончания второй мировой войны. М., 1960; Юрьев К.И. Экономика и внешнеполитические связи Демократической Республики Вьетнам. М., 1960; Экономическое сотрудничество н взаимопонимание социалистических стран. М., 1962; Международные отношения. Политика. Дипломатия. М., 1964; Международные отношения после Второй мировой войны. М., 1965; Нихамин В.П. Международные отношения в Юго-Восточной Азии (1945-1965 гг.). М., 1965; Кадымов Г.Г. Путь к независимости (Антиимпериалистическая борьба народов Вьетнама, Лаоса и Камбоджи). М., 1966; Жуков Ю., Шарапов В. Отпор. 1965-1966. М., 1966; Якимова Т.А. Некапиталистическнй путь развития ранее отсталых стран. М., 1968; Зайцев К.А. Экономическое сотрудничество и помоць СССР в развитии экономики Демократической Республики Вьетнам: Автореф. канд. экон. наук. М., 1969; Нстория Вьетнама в новейшее время (1917-1965). М., 1970; Международные конфликты. М., 1972; Очерки международных отношений в Южной, Юго-Восточной Азии и на Дальнем Востоке после Второй мировой войны (1945-1955). М., 1975.

24 Шедров Н.М. Гроза над Красной рекой. Репортаж из Демократической Республики Вьетнам. М., 1967; Мазаев А.Г., Щедров И.М. Агрессия США в Индокитае. М., 1971; Александров И. Эскалация позора (Агрессия США в Индокитае). М., 1972; Михеев Ю.А. Индокитай: путь к миру. М., 1977; Дивкльковский С.И., Огнетов И.А. Путь к победе: Очерк борьбы за национальную независимость, единство, мир и социализм во Вьетнаме (19451976 гг.). М., 1978; Военно-блоковая политика империализма: история и современность /Іод ред. П.А. Жилина, Р. Брюля. М., 1980; Глазунов Е.П., Исаев М.П. Страны Индокитая: пути борьбы и свершений. М., 1984; Исаев М.П. Индокитайская хроника. М., 1987; Интернациональное сотрудничество КПСС и КПВ: история и современность. М., 1987 к др.

Сладковский М.И. Экономические связи между СССР и ДРВ // Современный Восток. 1959. № 6; Васильцов В., Зеленцов В. Социалистические преобразования в экономике Демократической Республики Вьетнам // Вопросы экономики. 1959. № 12; Щевель И. Кредиты и безвозмездная помощь в отношениях между странами 
стремление советских авторов показать положительный опыт сотрудничества между СССР и ДРВ.

После окончания Второй индокитайской войны и вплоть до 1991 г. экономическая составляющая не являлась предметом специальных исследований. Тем не менее, отечественные историки интересовались данной проблематикой в контексте изучения общих вопросов истории стран Индокитая. Среди таких работ следует отметить исследования М.П. Исаева, А.С. Чернышева, Ю.Я. Михеева, А.С. Воронина и др. ${ }^{26}$.

Значительный теоретический и фактический материал содержится в трудах данного периода, затрагивающих обшие проблемы международных отношений в ЮBA $^{27}$. В указанных работах советский фактор в развитии экономики ДРВ не являлся предметом специального исследования, однако практически в каждом из указанных исследований присутствует их общая характеристика.

Следующий этап в исследовании экономической составляющей взаимоотношений ДРВ и СССР можно датировать началом 1990-х гг. и вплоть до настоящего времени. В этот период появляются работы, в которых некоторые отечественные авторы отказываются от идеологических установок периода «холодной войны» ${ }^{28}$.

В этот же период выходят исследования, касающиеся непосредственно военной истории, а именно - новый взгляд на события Второй индокитайской войны, где прослеживаются порой диаметрально противоположные оценки как мотивов военной помощи ДРВ со стороны СССР, так и специфики этой помощи ${ }^{29}$.

Значительный интерес с точки зрения выявления и определения роли советского фактора в процессе развития экономики ДРВ представляют некоторые диссертационные работы, монографии, статьи, вышедшие в последние годы ${ }^{30}$. Их

народной демократии // Деньги и кредит. 1961. № 9; Воцин М., Милюкова А, Норенков П. Торговля и зкономическое сотрудничество СССР и ДРВ // Внешня торговля. 1963. № 3; Караваев Е.М. Советсковьетнамские внешнеэкономические связи. Учёные записки Ин-та междунар. отношений. М., 1963; Викентьев А. Экономическое сотрудничество СССР с другими странами социализма // Международная жизнь. 1966. № 4 и др.

26 Исаев М.П., Чернышёв А.С. Советско-вьетнамские отношения. М., 1975: их же: История советсковьетнамских отношений. М., 1986; Михеев Ю.Я. Индокитай: путь к миру. (Индокитайские проблемы в свете современного международного права). М., 1977; Воронин А.С. Вьетнам сегодня. М., 1979 и др.

27 Черкасов 11.П. Франция и Кндокитай. 1945-1975. (Эволюцня французской политики в Индокитае). М., 1976; Международные отношения в Южной, Юго-Восточной Азии на Дальнем Востоке (1955-1965). М., 1978; Международные отношения в азиатско-тихоокеанском регионе. М., 1979; Страны Индокитая в борьбе за независимость и социальный прогресс (60-70-е годы). М., 1980; Вьетнам в борьбе. М., 1981; Внешняя политика стран. Азии. М., 1983; Новейшая история Вьетнама. М., 1983; Поспелов Д.М., Степанов Е.Д. Пекин против Вьетнама (60-е - начало 80-х годов). М., 1983; Исаев М.П., Пивоваров Я.Н. Внешняя политика Социалистической Республики Вьетнам. М., 1983; Глазунов Е.П., Нсаев М.П. Страны Индокитая. Путь борьбы и свершений. М., 1984; Черкасов П.П. Распад колониальной империи Франции. М., 1985; Исасв М.П. Современный революционный процесс в странах Индокитая. Проблема перерастания национально-освободительных революций в социалистические. М., 1985 и др.

28 Индокитай на рубеже веков (политика, идеология). М., 2001; Системная история международных отношений в двух томах. Под ред. Богатурова А.Д. Т. 2. События 1945-2003 годов. М., 2007; Исторня Востока: в 6 тт. Т. 6: Восток в новейший период (1945-2000 гг.). М., 2008. и др.

29 Ильинский М.М. Индокитай. Пепел четырёх войн (1939-1979 гг.). М., 2000; Война во Вьетнаме: взгляд сквозь годы... М., 2000; Дэвидсон Ф.Б. Война во Вьетнаме (1946-1975 гг.). М., 2002 и др.

30 Крапнвин М. С. Торгово-экономические отношения СССР, Россия со странами Юго-Восточной Азии : дисс... канд. эконом. наук: М., 2007. Кобелев Е.В. Современный Вьетнам: реформы, обновление, модернизация (1986-1997), M., 1999; Gaiduk I.V. Confronting Vietnam: Soviet Policy Toward the Indochina Conflict, $1954-1963$. Wach., 2003; Мазырин В.M. Реформы переходного периода во Вьетнаме (1986-2006): направления, динамика и результаты. М., 2007; Селиванов И.Н., Конорева И.А. Международные отношения в Индокитае: геополитика, дигломатия, правовые проблемы (1939-1954). Курск, 2008; Конорева И.А. Советский Союз и Индокитай: 1943- 
отличительной особенностью

является стремление большинства авторов непредвзято, с объективных позиций интерпретировать факты и исторические процессы, происходившие во второй половине XX в. в истории экономических отношений между ДРВ и СССР.

В СССР первые работы вьетнамских исследователей стали появляться в конце 1950-х - начале 1970-х гг. в формате монографий и статей ${ }^{31}$. Как правило, в такого рода работах был сделан акцент на характеристике особенностей формирования национальной экономики страны, начиная с вопросов укрепления денежно-кредитной системы (Ле Вьет Луонг, Чинь Ван Бинь, Тран Линх Шен), развития сельского хозяйства (Нгуен Ван Тхуан), промышленности (Нгуен Зуй Чинь, Нгуен Ван Кинь, Во Нян Чи). Отличительной особенностью указанных публикаций была их идеологическая направленность, обусловленная необходимостью подчеркивать позитивную значимость опыта и материальной помощи СССР в области развития народного хозяйства дРВ ${ }^{32}$. В диссертационных работах вьетнамских исследователей наблюдалась аналогичная тенденция ${ }^{33}$.

В работах, написанных в постсоветский период, присутствует более объективный анализ экономического развития ДРВ и роли советского фактора. Это прежде всего относится к исследованиям Бук Куок Хунга, Ле Тхань Лыонга, Чан Зюи Лиена, Нгуен Куанг Хи, Фам Тхи Нгок Бик и др. ${ }^{34}$

1976. Курск, 2011; Гайдук Н.В. Советский Союз и война во Вьетнаме // Осмысление истории. М., 1996; Индокитай: 1990 - е годы (политика, экономика). М., 1999; Война во Вьетнаме: взгляд сквозь годы...; Материалы научнопрактической конференция: «Советско-вьетнамское военное и экономическое сотрудничество в годы агрессии США против ДРВ (1964-1973гг.)». М, 2000; Индокитай: тенденции развития. М., 2004; Фам Тхи Нгок Бик, Мосяков Д.В. Внешняя полнтика Вьетнама в годы Второй индокитайской войны (1964-1975) // Восток. 2005. №2; Крапивин М.С., Мосяков Д.В. Отношения Советского Союза с Вьетнамом (60-90-е годы XX века.) // Восток., 2006. №3; Селиванов И.Н. Проблема представительства Вьетнама в ООН во второй половине 40-х - конце 50-х гг. XX в. и позиция СССР (по архивным материалам МИД РФ) // Проблемы истории международных отношений в новое и новейшее время. Тамбов, 2006; Кобелев Е.В. Российско-вьетнамские отношения: история и современность // Позиция России в АТР. М., 2007; Конорева И.А. Первый крупный локальный конфликт периода «холодной войны» // Азия и Африка сегодня. 2008. №7; Тихонов П.Г. Взаимоотношения СССР, КНР и ДРВ в первой половине 60-х годов XX века // Вестник Самарского государственного университета. 2008. №4; Мазырин В М. Россия и Вьетнам: Экономическое сближение: сдвиги и проблемы // Азия и Африка сегодня. 2010. № 5; Нванов В.В. Советсковьетнамское сотрудничество и позиция КНР в 1965-1967 гг. // Россия и АТР. 2010. №4; Вьетнамские исследования. Вьетнам сегодня и вчера. М., 2011 и др.

31 Буй Конг Чынг. Новый зтап сопиалистического развития Демократической Ресгублики Вьетнам // Народы Азии и Африки. 1961. № 6; Ву Нгок Кхуз. Некоторые вопросы финансов в первом пятилетнем плане ДРВ (Статья из ДРВ) // Финансы СССР. 1964. № 3; Буй Конг Чынг. Северный Вьетнам на пути построения социализма. М., 1959; Наш президент Хо ІІІи Мин. Ханой, 1972 и др.

32 Ле Вьет Луонг. Развитие и укрепление денежно-кредитной системы ДРВ // Деньги и кредит. 1960. № 9; Чинь Ван Бинь. Развитие финансов ДРВ // Финансы СССР. 1961. № 1; Тран Линх Шен. Расширение кредитных отношений государственного банка с промышленностью // Деньги и кредит. 1962. № 8; Нгуен Ван Тхуан. Олыт экономического районнрования ДРВ // Вестник Моск. ун-та. География. 1966. № 6; Нгуен Зуй Чинь. 430 миллионов рублей на индустриализацию Вьетнама // Новое время. 1961. № 2; Нгуен Ван Кннь. Экономика Демократической Республики Вьетнам на пути к социализму (пер. с вьетн.) // Вопросы зкономики. 1960. № 9; Во Нян Чи. Развитие экономики Демократической Республики Вьетнам (пер. с вьетн.) // Народы Азии и Африки. 1970. № 3; его же: Экономика ДРВ в условиях войны // Международная жизнь. 1968. № 2 и др.

33 Во Куан Тин. Социалистическая индустриализация народного хозяйства Демократической Республики Вьетнам (ДРВ) : дисс. ... канд. эконом. наук. М., 1963 и др.

3. Буй Куок Хунг. Опыт индустриального развития стран Азии и Вьетнама: дисс... канд. эконом. наук. М., 1997; Ле Тхань Лыонг. Внешнеэкономическая деятельность и ее влияние на развитие экономики во Вьетнаме, 1975-1997 rr.: дисс... докт. эконом. наук. М., 1998; Чан Зюи Лиен. Эволюция внешнеэкономической политики и территориальной структуры внешней торговли Вьетнама, 1900-2000 гг: дисс.. канд. эконом. наук : М., 2002; Нгуен Куанг Хи. Развитие торговых отношений Вьетнама с Россией : дисс... канд. эконом. наук. М., 2005; Фам Тхи Нгок Бик Внешняя политика Вьетнама в период второй ицдокитайской войны: от Женевской конференции до Парижской мирной конференции: 1954-1973 гг.: дисс... канд. ист. наук. М., 2005 и др. 
В монографиях некоторых вьетнамских авторов, выходивших на английском языке, присутствовал критический анализ экономической ситуации, в том числе проблем, появившихся в результате внедрения в экономику ДРВ принципов командно-административной системы, свойственных социалистическому способу производства, хотя сам термин в них не использовался ${ }^{35}$. Присутствовал тезис о недостаточной эффективности оказывавшейся Советским Союзом экономической помощи в строительстве на территории ДРВ народнохозяйственных объектов, высказывались сомнения в вопросах необходимости для Вьетнама получения отдельных групп товаров ${ }^{36}$.

В зарубежной англоязычной немарксистской историографии анализ экономического сотрудничества между ДРВ и СССР пока не нашёл достаточного освещения. Фактор советского участия в процессе экономического становления ДРВ рассматривался в нескольких аспектах. Один из них - советская военная помощь в период Второй индокитайской войны, поставка промышленных товаров, оборудования, помощь в подготовке квалифицированных кадров для народного хозяйства и военных специалистов. Исследователи (Д. Пайк, А. Пэн, М. ХэришІ, Х. Купер и др.) были практически единодушны в своих оценках - победа ДРВ во Второй индокитайской войне обеспечивалась большими объёмами помощи, получаемыми от СССР, КНР и других социалистических стран ${ }^{37}$.

Отдельные вопросы экономической помоши ДРВ со стороны СССР нашли отражение в исследованиях по военной истории, вышедших после 1973 г. В работах Г. Саммерса, Ст. Ларсен, Дж. Коллинза, Дж. Хэллманна, Э. Шорта, У. Гиббонса, Х. МакМастера, К. Хесса, С. Такера были рассмотрены различные версии причин победы ДРВ в войне с США. В качестве определяющей выступала экономическая помощь, оказываемая ДРВ СССР, КНР и другими социалистическими странами в рассматриваемый периоде

35 Teng Lang Tan. Economic Debates in Vietnam: Issues and Problems in Reconstruction and Development (1975-84). Hanoi, 1985; Nhân Trí Võ. Vietnam's Economic Policy Since 1975. Institute of Southeast Asian. Hanoi, 1990; Phong Đạng, Melanie Beresford. Authority Relations and Economic Decision-Making in Vietnam: An Historical Perspective. NIAS Press, 1998; The Anti-U.S. Resistance War for National Salvation 1954-1975: Military Events. Hanoi, 1980 (Foreign Broadcast Information Service, 1982); Vuong Quan Hoang. Fledgling Financial Markets in Vietnam's Transition Economy, 1986-2003. Hanoi, 2005; Keat Gin Ooi. Southeast Asia: A Historical Encyclopedia, from Angkor Wat to East Timor, V. I. ABC-CLIO, 2004; Thi Nhiem Phan, Charles Harvie, Van Hoa Tran. Vietnam's Economic Transition: Policies, Issues and Prospects / ICFAI Books, 2006; Nguyen Van Tin. Pleime Battle's Diary. Colonel Hieu, II Corps Chief of Staff. http://www.generalhieu.com/pleime_hieu_diary-2.htm; Nguyen Van Tin. Pleime Campaign and Pleiku Campaign. - http://nguyentin tripod.com/pleime_pleiku_kinnard_hieu-2.htm; Quan He Viet Nam - Lien Xo Trong Nhung Nam 1965-1975 TS. Nguyễn Thị Mai Hoa http://vietsuky, wordpress.com/2012/01/20/52-quan-he-viet-nam-lienxo-1965-1975/

36 Ле Хонг Тхай. Отношения СРВ с Россией в новых международных отношениях // Индокитай: тенденции развития. M., 2004; Vuong, Quan Hoang. Financial Markets in Vietnam's Transition Economy: Facts, Insights, Implications. Hanoi, 2010.

${ }^{37}$ Pike D. Vietnam and the Soviet Union: anatomy of an alliance. N.Y., 1987; Pan A. Soviet Aid to Vietnam. The Reporter // Central Intelligentce Agency Intelligence Report, Approved for Release date: May 2007; Harish C. M. Soviet Biscuit Factories and Chines Financial Grants: North Vietnam's Economic Diplomacy in 1967 and 1968. The Journal of The Society for Historians of American Foreign Relations-Diplomatic History. Volume 36, Issue 2, Ohio, 2012; Cooper C. L. The Lost Crusade. The Full Story of US Involvement in Vietnam from Roosevelt to Nixon. L., 1971 и дp.

${ }^{38}$ Summers H. G., On strategy : A critical analysis of the Vietnam war. N. Y., 1984; Larsen. S.R., Collins Jr., James L. Allied Participation in Vietnam. Wash., 1985; Hellmann J. American myth and the legacy of Vietnam. N.-Y., 1986; Short A. The Origins of the Vietnam War. L., N. Y., 1989; Gibbons W.C. The U.S. Government and the Vietnam War: Executive and Legislative Roles and Relationships, Part IV: July 1965-January 1968. Princeton, 1995; McMaster H.R. Dereliction of duty : Lyndon Johnson, Robert McNamara, the Joint Chiefs of Staff, the Lies that Led to Vietnam. N. Y., 1998; Hass K.A. Carried to the Wall: Amer. Memory a. the Vietnam Veterans Memorial. Berkeley, 1998; Tucker S.C., 
Помимо проблем, связанных с изучением военной истории, зарубежная историография представлена работами, предметом исследования в которых выступал процесс становления экономики ДРВ (СРВ). В трудах Р. Сэнсома, М. Рибоуда, Р. Бейкера, Б. Роуз, Д. Смита, М. Бересдорфф, Г. Олсон, У. Тюрлей, Л. Сорлей, Г. Лангера, Я. Джефрис, Дж. Картьер и др. отмечается, что экономическая политика СССР в середине 1950-х - середине 1970-х гг. была направлена на поддержку ДРВ в качестве государства, ставшего на путь построения социализма. В данных работах заметно стремление авторов доказать тезис о том, что СССР имел большое влияние на руководство ДРВ, поскольку - и это признавали многие исследователи - сила влияния СССР должна была быть пропорциональна количеству оказываемой помощи, что на самом деле таковым не являлось ${ }^{39}$.

Лишь в последние годы в работах зарубежных авторов, благодаря появлению рассекреченных архивных материалов и новейших исследований, появляется тезис о «неуправляемости» вьетнамцев, их восточной «политической специфике» и т. д. ${ }^{40}$

Большинство современных зарубежных авторов пришли к выводу, что помощь СССР имела негативные последствия для экономического развития ДРВ, поскольку произошло полное копирование советской командноадминистративной системы, что не способствовало зффективному экономическому развитию Вьетнама и привело впоследствии к отказу от советской модели хозяйствования.

Проведенный анализ позволяет констатировать, что тема советского участия в становлении и развитии северо-вьетнамской экономики изучена недостаточно и предлагаемое диссертационное исследование может, в определённой мере, восполнить этот пробел.

Апробация работы. Диссертация обсуждались и получила положительную оценку на заседании кафедры всеобщей истории Курского государственного университета, её основные положения отражены в 8 публикациях общим объёмом 5,1 п.л., в том числе 4 - в изданиях, рекомендованных ВАК РФ.

Структура работы. Диссертация состоит из введения, двух глав, заключения, списка использованных источников и литературы.

The Encyclopedia of the Vietnam War: A Political, Social, and Military History: A Political, Social, and Military History. Santa Barbara, 2011.

39 Sansom, R L., The economics of insurgency in the Mekong Delta of Vietnam. L., 1970; Riboud M. Face of North Vietnam. N.Y., 1970; Barker R., Rose B.. Appendix to the Rice Economy of Asia. Wash., 1985; Smith D. W., Economic and Social Development in Pacific Asia. Routledge, 1993; Beresford M., Phong Đáng. Economic Transition in Vietnam: Trade and Aid in the Demise of a Centrally Planned Economy. Northampton, 2000; Olson G.A., Turley W.S.. Landmark Speeches on the Viemam War. The Democratic Republic of Vietnam since the death of Ho Chi Minh: the politics of a revolution in transition. Texas, 2003; Sorley L. Vietnam Chronicles: The Abrams Tapes, 1968-19\%2. Texas, 2004; Langer H. The Vietnam War; An Encyclopedia Of Quotations. Westport, 2005; Jeffries I. Vietnam: A Guide to Economic and Political Developments. London, 2007; Carter J.M, Inventing Vietnam: The United States and State Building, 1954-1968. Cambridge, 2008.

${ }^{40}$ Womack B. China and Vietnam: The Politics of Asymmetry. Cambridge University Press, 2006. 


\section{ОСНОВНОЕ СОДЕРЖАНИЕ ДИССЕРТАЦИИ}

Во Введении обоснована актуальность темы, определены объект и предмет исследования, обоснованы хронологические рамки, сформулированы цель и задачи диссертации, определены ее научная новизна, теоретическая и практическая значимость, охарактеризована методологическая основа исследования, дан источниковедческий обзор и показана степень научной разработки проблемы.

Первая глава «Особениости формирования экономнчески связей между СССР и ДРВ в процессе становления национальной экономики страны в 1955-1965 гг.» начинается с параграфа «Исторические условия становления экономики ДРВ (1945 - 1954 гт.): международный аспект», который носит вводный характер. В нём рассмотрены события истории Вьетнама, предшествующие изучаемому в работе периоду.

В параграфе отмечается, что со второй половины XIX в. страны Индокитая (Вьетнам, Лаос и Камбоджа) входили в состав Французской колониальной империи. В годы Второй мировой войны Франция и Япония осуществляли совместное управление этими территориями, но в марте 1945 г. Японией была ликвидирована французская администрация, и Вьетнам был объявлен «независимым государством», входяшим в японскую «сферу сопроцветания Великой Восточной Азии».

В указанный период руководство Советского Союза не принимало непосредственного участия в решении проблем Индокитая. Вопросы, связанные со странами Юго-Восточной Азии, обсуждались лишь в рамках предполагаемых перспектив послевоенного политического устройства.

Благоприятные условия для освобождения Вьетнама сложились в середине 1945 г. Наступление союзников способствовало подъёму вьетнамского революционного движения во главе с Хо Ши Мином, что привело к провозглашению 2 сентября 1945 г. Демократической Республики Вьетнам (ДРВ). Франция не признала ДРВ де-юре, однако пошла с ее руководством на проведение переговоров о будущем ее статусе. Инициированный французской стороной раскол Вьетнама на две части (на юге Вьетнама у Франции была значительная поддержка местного населения) привёл к возникновению первого индокитайского локального военно-политического конфликта 1946-1954 гг., в ходе которого СССР официально признал правительство Хо Ши Мина.

Советская помощь ДРВ стала осуществляться через территорию Китая после октября 1949 г. СССР также оказывал идеологическую поддержку сторонникам Хо Ши Мина. Именно в это время наметился процесс создания фундамента двусторонних отношений, складывания основ экономического сотрудничества двух стран.

В параграфе сделан вывод, что после подписания Женевских соглашений 1954 г. начался этап более активного вовлечения СССР в дела Индокитая. Руководство ДРВ в этот период стремилось к расширению международных связей, в том числе с целью получения поддержки в создании национальной экономики. Советскому Союзу, наряду с КНР отводилось важное место в решении насуцных экономических проблем ДРВ. 
Во второл параграфе «Роль советской помощи в период послевоенного восстановления экономики ДРВ (1955-1960 гг.)» дана общая характеристика ситуации во Вьетнаме после 1954 гг., показаны особенности выработки основ экономической политики вплоть до середины 1960-х гг. Особое внимание в этом разделе уделено рассмотрению экономической составляющей взаимоотношений ДРВ и Советского Союза, определению места и роли СССР в процессе становления и развития экономики Вьетнама, выявлению основных направлений экономического развития ДРВ.

В параграфе отмечено, что сложившееся экономическое состояние вынуждало правительство страны изыскивать возможности для преодоления серьёзного кризиса, в котором находилась страна.

С этой целью предполагалось разработать годичный план восстановления и развития народного хозяйства. В июле 1955 г была достигнута договорённость о советской помощи Вьетнаму, чем была продолжена политика, направленная на развитие научно-технического и экономического сотрудничества. Подписание 18 июля 1955 г. Торгового соглашения СССР с ДРВ стало началом постоянных контактов между двумя странами в сфере экономики.

Реализация достигнутых договоренностей привела к тому, что при финансовом, техническом и кадровом содействии СССР в Северном Вьетнаме были построены ряд промышленных объектов, на базе открытых месторождений полезных ископаемых развернуто масштабное строительство предприятий горнорудной и угольной промышленности, в ДРВ направлялись советские специалисты, в СССР обучались вьетнамские граждане. Значительные усилия были направлены на достижение стабильности денежной системы и упорядочение цен. Серьёзной проблемой была нехватка товарной массы, недостатки в организации государственной торговой сети и снабженческо-сбытовой кооперации, а также широкие рамки свободного рынка, недочеты в работе государственного банка по регулированию денежного оборота. Учитывая сложное экономическое положение республики, Советский Союз к концу 1956 гг. направил ДРВ в качестве безвозмездной помощи большую партию продуктов и товаров широкого потребления.

В 1956 г., согласно Женевским договорённостям, на территории Вьетнама должны были пройти всеобщие выборы, но они были сорваны по инициативе США и правящего режима в Южном Вьетнаме. ДРВ и Южный Вьетнам продолжили развиваться по разным экономическим моделям.

В этих условиях Советский Союз, отказавшись признать проамериканский режим в Южном Вьетнаме, оказывал помощь ДРВ в развитии сырьевой и топливной базы экономики, способствовал реализации её энергетической политики, предполагавшей создание гидроэнергетики наряду с производством энергии на теплоэлектроцентралях. Значительную помощь оказал Советский Союз и в вопросе о платежах, пойдя на подписание в марте 1957 г. Соглашения о неторговых платежах, которое регулировало принципы ведения расчетов через государственные банки СССР и ДРВ, что ускоряло оборот денежной массы.

С ноября 1958 г. В ДРВ началось создание государственнокапиталистических (смешанных) предприятий, а также кооперирование сельского 
хозяйства. В период осушествления трехлетнего плана преобразования и развития экономики (1958-1960 гг.) произошли изменения В производственных отношениях. Особенностью преобразований в ДРВ явилось создание смешанных государственно-частных предприятий, a также кооперативных форм собственности.

В этот период между СССР и ДРВ продолжался процесс заключения соглашений и договоров, имевших большое значение для экономического развития страны ${ }^{41}$. Всего к 1959 г. при содействии СССР в ДРВ было построено и введено в эксплуатацию 45 промышленных предприятий и объектов. Большое значение в осуществлении индустриализации ДРВ имело научно-техническое сотрудничество с СССР.

В конце параграфа сделан вывод о том, что в рассматриваемый период советская сторона оказывала поддержку в осуществлении социальноэкономических преобразований, которые заложили фундамент для превращения ДРВ в аграрно-индустриальную страну, содействовала созданию материальнотехнической базы ДРВ и превращения её в полноправного экономического партнёра. Правительство ДРВ при содействии СССР сосредоточило усилия не только на возведении народнохозяйственных объектов, подготовке квалифицированных кадров, но и на решение проблем, связанных с формированием и структурированием финансовой системы страны. Результатом сотрудничества стали итоговые цифры, подведённые в связи с выполнением трёхлетнего плана развития народного хозяйства.

$B$ mретьем параграфе «Первый пятилетний план развития народного хозяйства ДРВ (1961-1965 гг.): значение экономического участия СССР в процессе его реализацин" представлен анализ вьетнамо-советских экономических отношений в период выполнения первого долгосрочного плана развития экономики ДРВ. В декабре 1960 г. было подписано очередное соглашение, в соответствии с которым Советский Союз предоставлял правительству ДРВ крупный кредит.

Значение экономической помощи Советского Союза ДРВ в параграфе выявлено из соотношения внутренних и внешних поступлений в доходную часть государственного бюджета ДРВ, что представлено в работе авторской таблицей и графиками: если в 1960 г. поступления из внутренних источников составляло $82,6 \%$, из внешних - $17,4 \%$, то к середине первой пятилетки показатели были соответственно $79,5 \%$ и 20,5\%. Это свидетельствовало о том, что развитие экономики ДРВ напрямую зависело от внешней поддержки социалистических стран.

СССР участвовал в создании и улучшении госхозов, в результате чего производство местных технических культур увеличилось в 5 раз. СССР обеспечил ДРВ грузовыми автомобилями, сельскохозяйственной техникой и дорожностроительным оборудованием, что способствовало росту производительности земледелия, улучшению коммуникаций и средств транспортировки воды.

${ }^{41}$ Переписка советского Посольства и правительства ДРВ об организации в СССР практики для вьетнамских специалистов (ноябрь-декабрь 1957 г.) // РГАЭ. Ф. 9493. Оп. 1. Д. 1154. Л. 157-163. 
Неплохо обстояли дела в области налаживания контактов в сфере торговли. 27 декабря 1963 г. был подписан протокол о товарообороте между СССР и ДРВ, которым предусматривалось дальнейшее увеличение товарооборота между обеими странами.

В Южном Вьетнаме в этот период наблюдался процесс еще большей политической нестабильности, что не могло не сказаться на общей политической ситуации в регионе. На этом фоне вмешательство США в индокитайские дела становилось всё более явным. Эти события совпали по времени с определённым спадом вьетнамо-советских отношений. Учитывая нежелание советского руководства, возглавляемого Н.С. Хрушёвым, ввязываться в конфликт в ЮгоВосточной Азии, руководители ДРВ стали активно развивать свои отношения с КНР. Вьетнамский Генштаб даже информировал советского военного атташе, что надобность в советских военных специалистах, выступающих в качестве инструкторов во Вьетнаме, отпала, и по истечении срока пребывания в ДРВ они должны покинуть страну

Смещение Н.С. Хрущёва с занимаемых постов скорректировало вектор внешней политики СССР в сторону укрепления позиций СССР в ЮВА. Активизация отношений между СССР и ДРВ проявилась в дальнейшем расширении экономических и военных контактов. В значительных объёмах было решено оказать поддержку ДРВ в финансовой сфере.

В параграфе также отмечается, что с середины 1950-х гг. характерным для развития государственных финансов ДРВ являлось то, что значительная часть средств для финансирования капитальных вложений покрывалась за счет кредитов и помощи социалистических стран. Во многом благодаря Советскому Союзу, уже к 1964 г. Северный Вьетнам в основном обеспечивал себя продовольствием, почти полностью - товарами массового потребления.

В 1965 г. в целях поддержки экономики страны правительство СССР согласилось перенести сроки выплаты основного долга ДРВ по кредитам на более позднее время. К 1965 г. СССР заключил с ДРВ пять межправительственных соглашений о содействии в развитии её экономики, в соответствии с которыми вьетнамской стороне была предоставлена значительная экономическая помощь. Эта помощь была использована для развития ведущих отраслей экономики ДРВ, создания необходимых предпосылок для проведения социалистической индустриализации.

Анализируя имеюшиеся данные, можно сделать вывод о том, что экономика ДРВ вплоть до начала американского вмешательства развивалась довольно высокими темпами. Завершив к 1961 г., в основном, преобразования частнокапиталистической промышленности и торговли, кооперирования кустарного производства и сельского хозяйства, в ДРВ в годы первой пятилетки (1960-1965 гг.) был взят курс на социалистическую индустриализацию. Впервые в истории страны там появились собственные машиностроительные, металлургические, химические и перерабатывающие предприятия, оснащенные высокопроизводительной техникой. Несмотря на начавшиеся военные действия, первая пятилетка по главным показателям была выполнена. 
Кроме того, исходя из основополагающего принципа экономического и технического сотрудничества - взаимовыгодности, можно констатировать, что многие товары, закупаемые СССР, начиная с момента установления более тесного торгового сотрудничества уже производились предприятиями, построенными при советском содействии. Помимо этих товаров, Советский Союз закупал в ДРВ продукцию местного сельскохозяйственного производства. Причём эти закупки вряд ли можно считать выгодными для СССР, поскольку данные категории товаров импортировались по завышенным ценам. С экономической точки зрения сотрудничество СССР с Северным Вьетнамом не являлось взаимовыгодным. Главным для СССР в этом сотрудничестве было распространение собственного геополитического и идеологического влияния, а не поиски экономической выгоды.

Для понимания стратегии построения экономических отношений СССР и ДРВ в параграфе представлены авторские графики динамики развития товарооборота и динамики предоставления кредитов и безвозмездной помощи (без учета фактической поставки товаров безвозмездно) 1955-1965гг. По мере развития отношений, СССР снижал уровень безвозмездной помощи и одновременно увеличивал объемы долгосрочных кредитов. Это свидетельствует о том, что Советский Союз стремился наладить с Вьетнамом полноценные взаимовыгодные экономические контакты.

Основываясь на современных методиках экономических исследований, с уверенностью можно сказать, что кредиты, предоставляемые СССР имели важное макроэкономическое значение. Они содействовали росту международной торговли, облегчали международные расчеты, способствовали появлению дополнительных финансовых источников для решения национальных проблем (используемых для покрытия дефицита госбюджета), позволяли регулировать платежный баланс, способствовали поддержке национальной валюты и борьбе с инфляцией. Также стоит отметить, что кредиты, выдаваемые СССР, имели для ДРВ выгодные условия и, прежде всего, низкие проценты ( $2 \%$ годовых). Вместе с тем получение слишком больших кредитов превращало ДРВ в несостоятельного должника и подрывало возможности ее социально-экономического развития. Как видно из представленного в работе графика, торговый баланс ДРВ был пассивным все время, начиная с 1955 г. и вплоть до 1965 г. Такое положение превращало ДРВ в несостоятельного должника, и в конечном итоге, вынудило правительство СССР в 1965 г. перенести выплату основного долга ДРВ по кредитам на более поздние сроки.

Таким образом, анализ динамики экономических отношений ДРВ и СССР в период 1955-1965 гг. позволяет сделать вывод, что сотрудничество в экономической, торговой и научных сферах, пройдя в своем развитии несколько этапов, позволило вывести ДРВ из состояния кризиса.

Сложившаяся в СССР командно-административная система со всеми ее отрицательными чертами копировалась руководством ДРВ. Тем не менее, был очевиден положительный результат: к 1965 г. ДРВ при поддержке со стороны социалистических стран фактически восстановила экономику, разрушенную в результате Первой индокитайской войны. 
В этот период появляются работы, в которых авторы отказываются от идеологических установок периода «холодной войны». Прежде всего следует отметить работы обобщающего характера, в которых вопросы советского экономического участия рассматривались в контексте не только идеологического противостояния, но и формирования мирового экономического рынка, подразумевающее включение стран третьего мира в происходившие интеграционные процессы. Условия экономического развития представлены не только с позиции реалий холодной войны, как это было в предыдущие годы, но с учётом интересов отдельных стран, народов ${ }^{30}$.

В этот же период выходит довольно много исследований, касающихся непосредственно военной истории, а именно - новый взгляд на события Второй индокитайской войны, где прослеживаются порой диаметрально противоположные оценки как мотивов военной помощи ДРВ со стороны СССР, так и специфики этой помощи ${ }^{31}$.

Значительный интерес с точки зрения выявления и определения роли советского фактора в процессе развития экономики ДРВ представляют современные исследования. Это касается диссертационных работ ${ }^{32}$, монографий $^{33}$, статей ${ }^{34}$, вышедших в последние годы. Их отличительной

30 Индокитай на рубеже веков (политика, идеология). М., 2001; Системная история международных отношений в двух томах. Под ред. Богатурова А.Д. Т.2. События 1945-2003 годов. М., 2007; История Востока: в 6 тт. Т.6: Восток в новейший период (1945-2000 гг.). М., 2008.

з1 Ильинский М.М. Индокитай. Пепел четырёх войн (1939-1979 гг.). М., 2000; Война во Вьетнаме: взгляд сквозь годы... М., 2000; Дэвидсон Ф.Б. Война во Вьетнаме (1946-1975 гг.). М., 2002 и др.

32 Крапивин М. С. Торгово-экономические отношения СССР, России со странами Юго-Восточной Азии : дисс... канд. эконом. наук : М., 2007.

33 Кобелев Е.В. Современный Вьетнам: реформы, обновление, модернизация (1986-1997), M., 1999; Gaiduk I.V. Confronting Vietnam: Soviet Policy Toward the Indochina Conflict, 1954-1963. W., 2003; Мазырин B.M. Реформы переходного периода во Вьетнаме (1986-2006): направления, динамика и результаты. М., 2007; Селиванов И.Н., Конорева И.А. Международные отношения в Индокитае: геополитика, дипломатия, правовые проблемы (1939-1954). Курск, 2008; Конорева И.А. Советский Союз и Индокитай: 19431976. Курск. 2011.

34 Гайдук И.В. Советский Союз и война во Вьетнаме // Осмысление истории. М., 1996; Индокитай: 1990 - е голы (политика, экономика). М., 1999; Война во Вьетнаме: взгляд сквозь годы...: Материалы научно-практической конференции: «Советсковьетнамское военное и экономическое сотрудничество в годы агрессии США против ДРВ 
именно эта особенность позволяла в значительной степени сокрашать военные потери.

Специфика советско-вьетнамского экономического сотрудничества в 1965-1968 гг. определялась условиями военного времени. Руководство ДРВ, находясь в состоянии эскалации войны с США, старалось развивать связи с СССР для получения, в первую очередь, военной помощи. Использование советского опыта экономического строительства являлось наиболее оптимальным, поскольку позволяло удерживать страну на уровне обеспечения минимальных жизненных потребностей населения. Копирование руководством ДРВ элементов плановой экономики, свойственных командно-административной системе СССР, в период военных действий было оправданно, поскольку позволяло контролировать процессы производства и распределения товаров народного потребления и восстановления экономики страны.

Во втором параграфе «Особенности экономических отношений между ДРВ и СССР на заключительном этапе Второй индокитайской войны (середина 1968 - начало 1973 гг.)» отмечается, что воздушная война, развязанная СШША против ДРВ, вопреки ожиданиям американских политиков и военных, не вызвала экономического хаоса в стране. Двухлетний план экономического развития (1966-1967 гг.) был выполнен по многим показателям. В 1968 г. было решено приступить к разработке и осушествлению трехлетнего плана (1968-1970 гг.) развития экономики.

Помимо запланированных мероприятий по развитию национальной экономики, руководство Северного Вьетнама активно стремилось использовать любые возможности для решения насушных задач и увеличения экономического потенциала ДРВ, в том числе используя безвозмездную гуманитарную помощь социалистических стран.

Согласно имевшимся договорённостям, с конца 1967 г. в ДРВ направлялись советские «корабли солидарности», доставлявшие закупленные на средства советских общественных организаций медикаменты, продовольствие и одежду.

Большое внимание советской стороной продолжало уделяться подготовке квалифицированных специалистов для народного хозяйства ДРВ. Научнотехническое сотрудничество осуществлялось по линии специальной советсковьетнамской комиссии, продолжался обмен научными делегациями, осушествлялись активные связи между Академией наук СССР и Государственным комитетом науки и техники ДРВ.

Тем не менее, в указанный период от советских представителей, осуществлявших непосредственные поставки товаров в ДРВ, поступали сведения об имеющих место фактах небрежного отношения вьетнамской стороны к поставкам из СССР. Если ранее сложности возникали из-за специфики советскокитайских отношений, то к концу 1960-х гг. стала поступать информация о недопустимом поведении, как руководства отдельных структур, так и простых рабочих, осуществляющих приём поступающих продуктов и товаров народного потребления из СССР. Реакцией советской стороны стал более тщательный отбор товаров, поставляемых в качестве помощи. 
Еще в начале Второй вьетнамской войны наиболее дальновидным аналитикам в СССР было понятно, что решить индокитайскую проблему военным путем ни одна из сторон не сможет. Втягивание напрямую в нее СССР бесперспективно, а советские ПВО не в состоянии помешать американским бомбардировкам ДРВ. Поэтому необходимо было убедить руководство ДРВ искать дипломатические пути решения проблемы. Кроме того, курс на «независимость» в отношениях с СССР со стороны ханойских лидеров и угроза перерастания локального конфликта в международный, подталкивали советское руководство К активизации деятельности по скорейшему мирному урегулированию ситуации. Даже такие «плюсы» для СССР, как испытание советской военной техники в условиях реальных боевых действий и получение от вьетнамской стороны данных о новейших вооружениях США, не перевешивали желание прекратить войну. Кроме того, в экономическом отношении помошь ДРВ являлась обременительной для СССР, поскольку требовались постоянные сушественные вливания в ее экономику.

Прекращение с ноября 1968 г. американских бомбардировок территории ДРВ создавало условия для перехода к восстановлению народного хозяйства, подорванного четырехлетней войной. В 1969 г. в Ханое было подписано двустороннее соглашение о воздушном сообщении между ДРВ и СССР, которое имело большое значение в расширении связей между двумя странами. Осенью 1969 г. по приглашению ЦК КПСС и Советского правительства в Москве находилась партийно-правительственная делегация ДРВ, которая провела серию переговоров, по итогам которых были подписаны соглашения об оказании Советским Союзом дополнительной помоши ДРВ. В параграфе отмечается, что руководство ДРВ воспринимало оказываемую им помощь как «обязанность» стран социализма в связи с декларируемыми ими идеями поддержки развивающимся странам.

К 1972 г., согласно имеющимся договоренностям, советские специалисты участвовали в строительстве на территории ДРВ 56 промышленных предприятий и других объектов ${ }^{42}$. Содействие в развитии народного хозяйства ДРВ оказывали тысячи высококвалифицированных советских специалистов.

Кроме того, активная внешнеполитическая деятельность руководства СССР в 1971-1972 гг. в значительной степени способствовала решению проблемы восстановлении мира во Вьетнаме. Однако в Северном Вьетнаме неоднозначно оценили поездки Р. Никсона в СССР и КНР в 1972 г., но оказываемая военная и экономическая помощь ДРВ не позволяла открыто критиковать руководство CCCP.

В декабре 1972 г. было подписано дополнительное соглашение об образовании Межправительственнй советско-вьетнамской комиссии по

${ }^{42}$ Соглашение о строительстве линий электропередач Фалай-Винь оr 22.10 .1970 г. // АВП РФ. Ф. 79. ОП. 34. Д.11. Л. 3; Соглашение о реконструкиия оловянного рудника Тян Тук До от 7. 10. 1971 г. // там же. Л.1; Соглашение о поставке оборудования и материалов для угольного разреза Као Шон от 7. 10, 1971 г. // там же; Соглашение о выполнении проектных работ по расширению угольной шахты Вангзань от 7. 10.1971 г. // там же. JI. 6; Соглашение о строительстве мельничного комбината с элеватором от 7. 10. 1971 г. // там же. Л. 28 и др. 
экономическому и научно-техническому сотрудничеству, что привело к более активному развитию торговых связей.

Негативным фактором двустороннего сотрудничества в данный период следует считать то, что СССР, оказывая значительную помощь, автоматически распространял на ДРВ собственную модель экономического развития с командно-административной системой хозяйствования, структурными диспропорциями, недостаточной эффективностью использования инвестиционных ресурсов. В результате явного перекоса в сторону развития тяжелой промышленности, вложения оказались несопоставимыми с полученными ограниченными результатами. Последующая попытка руководства ДРВ сделать ставку на социалистическую индустриализацию советского типа тоже завершилась неудачно.

Тем не менее, в условиях войны помощь СССР являлась определяющей в достижении победы над мошным противником, а система социалистического хозяйствования позволила сохранить ДРВ, как самостоятельную экономическую единицу.

В параграфе сделан вывод, что развитие национальной экономики Вьетнама В период Второй индокитайской войны обеспечивалось сочетанием двух важнейших факторов - эффективной деятельностью руководства страны по мобилизации усилий государственного аппарата и населения, а также активной внешней поддержкой со стороны стран социализма и, прежде всего, Советского Союза. Специфика советско-вьетнамского сотрудничества в середине 1960-хначале 1970-х гг. определялась комплексом проблем, к которым следует отнести условия военного противостояния ДРВ и США, идеологическое противоборство СССР и США в рамках политики «холодной войны», проблемы интернационализации индокитайского конфликта. В целом, советско-вьетнамские отношения являли собой пример широкомасштабной акции по поддержанию сушествующей системы, ориентированной на создание во Вьетнаме основ социалистической экономики.

третий параграф «Советское участие в решении экономических проблем ДРВ накануне объедннения Вьетнама (январь 1973-апрель 1976 гг.)» начинается с анализа событий, связанных с условиями подписания 27 января 1973 г. Парижского мирного соглашения, отмечается, что оказанная СССР ДРВ военная, экономическая и моральная поддержка сыграли важную роль в военнополитическом поражении США в данном регионе.

С восстановлением мира во Вьетнаме советско-вьетнамские отношения вступили в новый этап, характеризуюшийся дальнейшим развитием сотрудничества СССР с ДРВ и $\mathrm{PЮB}^{43}$. КПСС и Советское правительство в июле 1973 г. приняли решение рассматривать кредиты, предоставленные Советским Союзом ДРВ в предыдущие годы на цели экономического строительства, в

43 Республика Южный Вьетнам была провозглашена в июне 1969 г. на освобождённых территориях представителями Национального Фронта Освобождения Южного Вьетнама (НФОЮВ), одновременно было образовано Временное революционное правительство Республики Южный Вьетнам (ВРП РЮВ). 
качестве безвозмездной помощи ${ }^{44}$. Своими действиями руководство Советского Союза значительно ускорило процесс послевоенного восстановления и развития экономики Северного Вьетнама. Кроме того, политические контакты СССР с ДРВ и РЮВ на высшем уровне получили в послевоенный период дальнейшее развитие, что способствовало упрочению советско-вьетнамских отношений.

Развитие экономики ДРВ могло успешно осушествляться лишь в условиях стабильной внешнеполитической ситуации. По этой причине обсуждение проблем стратегии США и других капиталистических стран в ЮВА занимало важное место в деятельности руководства ДРВ, основной задачей которого являлось сохранение стабильности в Индокитае и привлечение как можно большего числа инвесторов в развитие национальной экономики.

Основные направления сотрудничества ДРВ с социалистическими странами и, в частности, с Советским Союзом, вытекали из задач восстановления экономики путем повышения технического уровня производства и его эффективности, создания источников накопления для социалистической индустриализации, повышения материального благосостояния народа. В разработке программы развития республики большое внимание было уделено расширению экспортной базы, постепенному выравниванию темпов роста экспорта и импорта, ликвидации разрыва в их уровне. Ведущее место в торгово-экономическом сотрудничестве ДРВ, как и прежде, занимал Советский Союз. Эффективность помоши СССР проявлялась в том, что посредством экономических и торговых соглашений между странами создавались условия для содействия восстановлению и развитию традиционных экспортных производств и тем самым - благоприятные предпосылки для повышения эффективности и высокого роста внешнеторгового оборота ДРВ.

В целях оказания помощи ДРВ и подготовке квалифицированных национальных кадров советская сторона обязалась принять в 1973-1976 гг. 8 тыс. вьетнамских граждан для обучения в профессионально-технических училишах и техникумах. Советская сторона взяла на себя расходы, связанные с их обучением, советские специалисты приняли участие в строительстве дорог, в проведении геологоразведочных работ, а также в освоении целинных земель.

В параграфе отмечается, что в указанный период в практику связей СССР и ДРВ в народнохозяйственной области вошли регулярные встречи, совешания и консультации политиков и экономистов обеих стран по различным вопросам сотрудничества. Результатом стало подписание ряда соглашений, направленных на оказание помощи ДРВ. Тем не менее, наряду с вошедшими в практику формами поддержки вьетнамской экономики, такими, как списание долгов и оказание гуманитарной помощи, увеличивается число взаимовыгодных обменов и возможностей вкладывать средства в развитие экономики Вьетнама с перспективой получения прибыли.

В заключении подведены итоги исследования и сделаны обобщающие выводы.

${ }^{44}$ АВП РФ. Ф. 79. Оп. 28. Д. 9. Л. 20. Сумма на 1.07.1973 г. составляла около 1080.7 млн. руб. по основному долгу и начисленным процентам. 
Анализ динамики экономических отношений ДРВ и СССР в период 1955 1965 гг. позволяет сделать вывод, что сотрудничество в экономической, торговой и научных сферах, пройдя в своем развитии несколько этапов, позволило вывести ДРВ из кризиса: преодолеть главные трудности в восстановлении народного хозяйства после окончания Первой индокитайской войны, найти оптимально выгодные методы решения ее экономических проблем.

Начало Второй индокитайской войны явилось серьёзным испытанием для экономики ДРВ. Американская силовая политика в регионе не оставила выбора северовьетнамскому руководству в определении пути экономического развития, поскольку на повестке дня стоял вопрос о существовании ДРВ в качестве независимого государства. В случае предпочтения опыта капиталистического хозяйствования могло пронзойти поглощение ДРВ Южным Вьетнамом, находившемся в зависимости от США. В итоге курс на развитие экономики, основывающейся на социалистической системе хозяйствования, был сохранён, тем более, что лидеры СССР готовы были продолжать оказывать ДРВ значительную материальную помощь. В результате планомерных действий руководства ДРВ и поддержки социалистических стран промышленный потенциал ДРВ не только не был уничтожен, но, приобретя несколько иную структурную конфигурацию, значительно усилился.

В процессе становления национальной экономики Вьетнама негативным фактором следует считать то, что руководство ДРВ перенимало советскую модель экономического развития с командно-административной системой хозяйствования, структурными диспропорциями, недостаточной эффективностыо использования инвестиционных ресурсов. В результате явного перекоса в сторону развития тяжелой промышленности, вложения в неё оказались несопоставимыми с полученными ограниченными результатами.

Созданное в результате автоматического перенесения на Вьетнам командно-административной системы военизированное государство с дотационно-распределительной экономикой, руководимое методами централизованного планирования, всё же оказалось эффективным для решения в экстремальных условиях его руководством жизненно важных задач. Советская поддержка и способность вьетнамской правящей партии держать собственное население под контролем в сложных условиях войны и мирных передышек, обеспечили экономическое выживание ДРВ.

Советский фактор в развитии национальной экономики дРВ был определяющим и в значительной степени позволил обеспечить появление на политической карте мира в 1976 г. единого вьетнамского государства - СРВ. 


\section{Основные положения диссертации отражены в следуюших публикачиях автора:}

\section{I. Статьи, опубликованные в журналах, рекомендованных ВАК РФ:}

1. Коровяковский И.В. Советский Союз и международные локальные конфликты в Индокитае: середина 40-х-начало 70-х гг. XX в. // Ученые записки Российского государственного социального университета. Москва. 2010. № 3(79). С. $83-89 .(0,75$ п.л.)

2. Коровяковский И.В. Основные направления экономического сотрудничества СССР-ДРВ в период второй индокитайской войны 1965-1973 гг. Учёные записки: электронный журнал Курского государственного университета. 2011. №3 (19). T. 2. (0,75 п.л.) http://www.scientific-notes.ru/pdf/021-034.pdf, 218 Кб.

3. Коровяковский И.В. Советский фактор в развитии национальной экономики Вьетнама: середина 60-х-первая половина 70-х гг. XX в. // Ученые записки Российского государственного социального университета. Москва. 2011. №6(94). С.212-217. (0,65 п.л.)

4. Коровяковский И.В. Динамика развития экономических взаимоотношений между ДРВ и СССР в 1955-1965 гг. // Учёные записки: электронный журнал Курского государственного университета. 2012. №1 (21). $(0,85$ п.л.) http://www.scientific-notes.ru/pdf/023-015.pdf, 319 Кб.

\section{II. Прочие публикации:}

5. Коровяковский И.В. История советско-вьетнамских отношений: экономический аспект (1950-1964 гг.). // Проблемы преподавания и изучения истории зарубежных стран. Вып. 7, Курск: Изд-во КГУ, 2010. С. 40-51. (0,4 п1.л.)

6. Коровяковский И.В. Основные направления советско-вьетнамских экономических отношений в 1965-1991 гг. // Проблемы преподавания и изучения истории зарубежных стран. Выпуск 7, Курск: Изд-во КГУ, 2010. С. 61-72. (0,6 п.л.)

7. Коровяковский И.В. - Исторические условия становления Демократической Республики Вьетнам (1945-1954). // Проблемы преподавания и изучения истории зарубежных стран. Вып. 8. Курск: Изд-во КГУ, 2012. С. 25-32. $(0,8$ п. л.)

8. Коровяковский И.В. Эволюция экономических отношений СССР с Вьетнамом 1955-1991 гг. - http://www.tsutmb.ru/nu/nauka/index.php/razdel/meropr/2011.html?sobi2Task=sobi2Details\&catid=21\&sobi2Id=190 (0,3 п.л.). 
Коровяковский Илья Владимирович

\title{
Советский фактор в развитии экономики Демократической Республики Вьетнам (середина 1950-х - середина 1970-х гт.)
}

\author{
A6mopeфepam \\ Лицензия на издательскую деятельность \\ ИД № 06248 от 12.11 .2001 \\ Подшисано в печать 24.11.2012 \\ Формат 60X84/16 \\ Усл. печ. л. 1,6. \\ Тираж 100 экз. Заказ 2533
}

Издательство Курского государственного университега 305000 , г. Курск, ул. Радищева, д. 33.

Отпечатано в лаборатории информатионно-методицеского обеспедепяя КГу 